\title{
Le regard du vainqueur?
}

\author{
Nikolas Hächler and Marietta Horster
}

Can we answer the question "How Roman were the landscapes of the Roman empire?"1 from a non-Roman perspective? A simple answer is available neither on an epistemological nor on a methodological level. A naïve but all-embracing and practical working hypothesis might base the definition of landscapes as 'Roman' on the thoughts, feelings, and the evaluation of the Romans themselves, of few non-Romans, and of the scholars who are reading these lines and working on the subject. We should not, however, regard the issue as settled so easily. One may achieve a broader perspective, even if the Roman view remains dominant. For example, a focus on archaeology widens our view, whereas a focus on antique written sources reveals 'Roman' thoughts filtered through our lenses. Therefore, the authors of this volume zoomed in on different approaches. The papers incorporate vantage points of modern interpretation, cultural construction, and metalanguage, as well as hermeneutical analyses of ancient visual and written artefacts as testimonies for and remains of 'landscapes' - but whose landscapes? Southern landscapes of the Roman period can be studied on the macro-ecological level as part of the Mediterranean, which is characterised by a specific connectivity and flows of resources, goods, people, political power, and ideas. With their distinct geographical and political connectivity, these Mediterranean landscapes are different from the landscapes of, e.g., the north-western Roman provinces. ${ }^{2}$ The broader view of connectedness and embeddedness must prevent even a volume in the series "Impact of Empire" to draw on a simplistic dichotomy between Rome and all the other parts of the empire. As the editors and authors of this volume were aware of a

1 Bourdin categorised Greek geography as "regard médiatrisé", Greek historiography as "ethnographie", the Roman annalistic as "regard du vainqueur", and the antiquarian tradition as "exaltation des mores Italiae", St. Bourdin, Les peuples de l'Italie préromaine: identités, territoires et relations inter-ethniques en Italie centrale et septentrionale $\left(V_{I I I}{ }^{e} I^{e r}\right.$ s. av.J.-C.) (Rome 2012), 1191. In these more than 1200 pages, Bourdin addresses the issue of "landscape" identity of pre-Roman and Roman Italy in a variety of contexts.

2 P. Horden and N. Purcell, The Boundless Sea: Writing Mediterranean History (London and New York 2020); for different arguments for the "wider Mediterranean perspective" see T. Stek, 'Cult, conquest, and "religious romanization": the impact of Rome on places and religious practices in Italy', in T. Stek and G.-J. Burgers (eds.), The Impact of Rome on Cult Places and Religious Practices in Ancient Italy (London 2015), 1-28, here 5-6. 
persisting broader geographical framework than the Roman world and of the dynamics within the Roman world and changing perceptions of Romanness, they applied different approaches and premises to discuss the impact on landscape without risking to fall into the stumbling blocks of the debate on the term and the underlying concept of "Romanization" as a one-way road. ${ }^{3}$

What is 'Roman', at least from the Roman authors' point of view and in the context of discussing Roman identity? From the Republican to the late antique period, authors expressed ideas of and judgement about otherness in Latin or Greek, and they referred not only to 'barbarians' outside the gate or at the borders. The categories defining otherness shifted over time. Writers changed their perspectives and narratological strategies, and in most cases the discourse on otherness was seemingly not centred on a specific region, a distinct 'landscape', but on specific people or individual groups, defined by moral standards, manly virtues, social categories, or learnedness. ${ }^{4}$ Some authors promoted the idea that natural environment and climate zones influenced a people's character and social organisation. ${ }^{5}$

Against this backdrop, the problem of the term 'Romanisation' describing manifestations of Romanness and various processes of interaction, influence and categorisation seems less dramatic. This approach is not centred on ideas of colonialism as it is debated from a modern political perspective, although this term and debate naturally accompany any discussion of 'Roman'. But as much as the once "extremely value-laden term" Romanisation has been discussed and criticised in the last decades, it is still a "useful tool" ${ }^{6}$ to describe

3 G. Woolf, 'Beyond Romans and Natives', World Archaeology 28 (1996-1997), 339-35o. For an extensive bibliography on current terminologies to describe the interconnectedness of the Roman world see R. Haeussler and E. Webster, 'Creolage: a bottom-up approach to cultural change in Roman times', Theoretical Roman Archaeology Journal 3 (2020), 1-20, https://doi .org/10.16995/traj.419.

4 For various methods and approaches to "otherness" in Roman culture and literature with extensive references to earlier literature see G. Woolf, Tales of the Barbarians: Ethnography and Empire in the Roman West (Malden 2011), and M. Horster, 'Small-minded, envious and chauvinistic: the self-shaping of Roman intellectuals', in F. Pina-Polo (ed.), Xenophobia in the Ancient World (Barcelona 2019), 59-74, and other contributions with different focuses in Pina-Polo 2019, op. cit. (n. 4).

5 J. Weidauer, Männlichkeit verhandeln: Von Lüstlingen, Kriegern und wahren Römern (1./2. Jh. n. Chr.) (Heidelberg 2021), 141-148; on Strabo's climate theory in connection with 'natural' dominance and ruling power, see K. Clarke, Between Geography and History: Hellenistic Constructions of the Roman World (Oxford 1999), 295-296 and J.M. Vonder Bruegge, Mapping Galilee in Josephus, Luke and John: Critical Geography and the Construction of an Ancient Space (Leiden and Boston 2016), 63.

6 S. Keay, N. Terrenato, 'Preface', in S. Keay and N. Terrenato (eds.), Italy and the West: Comparative Issues in Romanization (Oxford 2001), IX-XII, here IX. 
aspects and phenomena of interaction and exchange that led to the creation of the Roman empire as a political and cultural unit. Coercion, adaptation, and all varieties of multilateral interaction between Romans and non-Romans, or Romans-not-from-the-centre-of-the-empire, created something new and by no means uniform. Differences were visible on all social levels and in local manifestations. Ideas of 'Roman' in the mid-Republic, when the first Roman provinces were created, were not identical to imperial period Roman identity. These changes correlated with shifts in the political system, the increase of dominated territory, and the number of provinces. Despite the rhetoric of unity of orders, of harmony of all Romans, of maintaining traditions, of mos maiorum, and of an economy continuously dominated by agriculture as the only traditional and reputable option, the Roman world was highly dynamic. While the reality was a composite culture with changing faces, ${ }^{7}$ the social traditions, political and religious institutions, architecture, aesthetic preferences, ideas, ideals, language, etc. continued to be labelled 'Roman' by Romans. Modern accounts react to this phenomenon for example by calling the epigrammatist and satirist Martial Hispano-Roman, or a less famous man from Gallia Belgica with tria nomina including some Celtic cognomen and with a 'poor' quality relief on his funerary slab Gallo-Roman. ${ }^{8}$

This modern perspective has antique roots in the later Roman empire. It seems, however, that already in earlier times the term 'Roman' lost its splendour of exclusiveness for parts of the Italian Romans. For a short time during or after the Civil wars of the late Republic, in the mid-first century CE, elite-members were admitted into the Roman senate for provincials from southern Gaul, as well as for many inhabitants all over the empire in the third century CE after the Constitutio Antoninina. This judicial aspect of being Roman had important consequences for political participation, social standing, legal protection, and economic opportunities. Some of our contributions will demonstrate that this had an impact on making a landscape 'Roman' as well. However, a 'Roman' landscape was most obviously marked by land distribution to newly settled Roman colonists. This colonising Romanness is still detectable in surveys, visible in aerial photographs, and readable on the inscribed stones not just on those terminating land lots. The effects of land distribution were just one of the colonial status of a city with its territory. Outside the city wall and within the territory, it was obvious in funerary contexts and in rural sanctuaries. The inscriptions setup in graveyards or as part of votive offerings refer to Romans

7 Cf. Keay 2001, op. cit. (n. 6), IX.

8 E.g. $C I L$ XIII $8655=$ CSIR Deutschland III 1.22 with plates 24-25: Silvanus, son of Loupus, a man from Trier, eques in the Roman army and stationed in Xanten. 
using their Roman names, mentioning their Roman voting districts (tribus), referring to Roman institutions and to a Roman status or career. This example of Rome-overloaded inscriptions creating funerary landscapes (a topic not addressed in this book) or Roman-related sacred landscapes (a topic twice addressed in this book) should have made obvious that despite the many perspectives, approaches and themes discussed in this anthology, the authors can only offer a few insights into the diversity and heterogeneity of a Roman landscape.

The space in which human action and interaction probably took place will play the leading role. This volume focusses on ideals, ideas, and concepts, as well as on institutions and material manifestations of Romanness in a city's territory and surroundings, in larger regions, and territorial units. The collection of papers, however, will give but a small insight into these issues of "glocal"9 vs. local processes. In sum, the rapidity, the timescale, and the character of the enforcement and impact of Roman actions, varied from region to region. The extent to which provincial boundaries, compared to demography, settlement patterns, and economic potential, influenced these processes is questionable. It seems that economic efficiency was more often determined by geological or climatic than by political conditions. Therefore, most of the following contributions focus on the local level, either within Italy or in one of the provinces or settlement areas. Similar effects, common themes, and connections become visible; differences in time and place become obvious as well. Some of the papers will explore a specific local, regional, or provincial context and consider the results of limited scope, if not in contrast to the effects in other areas of the Roman empire. This volume thus reflects the modern concept of a multifaceted, composite, multi-layered Roman world, but at the same time reduces its complexity. It views 'Roman' not only in the sense of power politics, but also in a cultural context. It highlights 'landscapes' and puts into the shadow important administrative and legal structures, i.e., cities and provinces, and main actors, viz. local and imperial members of the elites living in cities, which ran the empire. However, Roman landscapes are still connected to both the cities and the elites, notwithstanding which definition and facets of landscape are taken into account. In this volume, in contrast to the multifaceted usage of the landscape-terminology, the term and concept of 'environment' are considered as pre-existent to human agency, whereas a real or an ideal landscape is defined as conceptualised by human perception, as formed

9 For the concept of "glocalisation" see M. Pitts and M.J. Versluys, 'Globalisation and the Roman world: Perspectives and opportunities', in M. Pitts and M.J. Versluys (eds.), Globalisation and the Roman World: World History, Connectivity and Material Culture (Cambridge 2015), 3-31, here $13-15$. 
and changed by human activities, and as represented and communicated by language and visual artefacts.

It would have been tempting to focus on a specific landscape, for example Roman Gaul. With stone quarries, drained marshes, and its mining industry, its material remains are less obvious in its the landscape than the notorious paved Roman roads with milestones, legionary or auxiliary camps, aqueducts, large funerary monuments, or rural sanctuaries. Zooarchaeology, botanical analyses, and geodata analyses have added to the knowledge about the Romanisation of landscape; they investigated changes in arboriculture, the introduction of new crops, consumption patterns of Mediterranean food like olives, olive oil, and vine in the Gallic provinces, and changes of the amount and choice of animal husbandry. ${ }^{10}$ Little evidence remains to assess how 'Roman' the landscape of the late Republican province of southern Gaul was. Only the milestones of the Via Domitiana and traceable land division on the territory of the colony of Narbo give some indications. ${ }^{11}$ The testimonies from the imperial period are much richer; they include impressive remains like the Pont du Gard and the archaeological park of the imperial city Glanum. ${ }^{12}$ In the late antique period, authors like Sidonius praised living in a villa in the countryside, and Ausonius celebrated the beauty of Gallia Belgica's charming Mosella valley and poetically described travelling across the country.

However, Gaul will not be the focus of this volume. Only Deru and Auvertin touch historical developments in northern Gaul and discuss methodological options for their interpretation. Some authors will take up some of the examples from Gaul just mentioned. Weaverdyck refers to some findings from Gaul within his study of the Northern provinces. Kerschbaum focuses on aqueducts like the Pont du Gard, but in the eastern part of the empire. Gangloff discusses aspects of real and imagined villa life and otium in Italy. Köster, as well as Walker, analyse poetic descriptions of landscapes in words and images. Carlà-Uhink and Kolb each consider streets and milestones as creating specific Roman landscapes. Campedelli, Espanña-Chamarro, and Lefebvre all

10 See G. Woolf, Becoming Roman: The Origins of Provincial Civilization in Gaul (Cambridge 1998), 142-168 on these effects on the countryside in the Gallic provinces. Cf. the overview of Marietta Horster in this volume, providing further literature.

11 Woolf 1996-1997, op. cit. (n. 3), 345.

12 According to James Frakes, some features of cult architecture related capitals in Glanum seem neither Roman nor Celtic; they present "a vision of a larger world" merging influences of several Mediterranean cultures, J.F.D. Frakes, 'An architecture of human heads: Gallic responses to Roman power', in J.-J. Aubert (ed.), A Tall Order: Writing Social History of the Ancient World. Essays in Honor of William V. Harris (München and Leipzig 2005), 161-183, here 179 . 
discuss the role of streets and milestones in Spain for imposing a specific Roman imperial vision upon a space that had already been used and defined by Celt-Iberians and Punic authorities and traders. Lastly, Schörner addresses land division, the most obvious and brutal impact on landscape, again not in Gaul but in the heart of Italy.

The methodological approaches applied in this volume are sometimes controversial like the categorisation and statistics of groups of findings and places, and sometimes traditional like analysing inscribed milestones as claims of authority and imposing dominance. This volume demonstrates the potential of surveys, of archive studies, and of map analyses. Close reading and a Michel Foucault-inspired "archéologie" of ideas and terms reveal Roman legal concepts that entailed consequences for the definition of arable land and land of different (if not poorer) quality. The management of water by drainage systems in metaphorical contexts (Maticic) or in connection to supply (Kerschbaum) and natural impact (Bono) was among the many aspects of Roman cultural superiority (humanitas) and subtle methods of oppression (pars servitutis) mentioned in Tacitus's Agricola (21, balinea). This quintessential, arrogant, imperial Roman self-perception is drawn upon by modern views of Roman infrastructure, famously reflected (and parodied) in Monty Python's Life of Brian: "What have the Romans ever done for us?"

The fourteenth workshop of the network "Impact of Empire" took place in Mainz from 12th to 15th June 2019. Its topic, the Impact of Empire on Roman Landscape, addressed the world outside the cities and focused on how different spaces of the Mediterranean world became 'Roman' during the imperial age and, particularly, the later Roman empire. The contributions studied Rome's varied impact on the shaping and structuring of places, changes in the cultivation of land under its control, and the symbolic, literary, political, and legal creation of Roman landscapes. Discussions were centred on concepts of the empire, practices of mapping the Roman world, its narrative representations, and rituals and procedures of integrating landscapes into the Roman state. Furthermore, the workshop discussed public symbols that shaped and marked individual regions as Roman, as well as the appropriation and exploitation of land and its resources for the benefit of the Imperium Romanum. The book is structured in four parts starting with two introductory chapters in the first section. Inspired by the scene from Monty Python's The Life of Brian mentioned above, the second section of this volume focuses on Roman infrastructure and its impact on political landscapes. It deals therefore primarily with the processes of making an administrative unit 'Roman' by establishing public infrastructure. The papers within this section answer the question what the Roman state actually did for its inhabitants, how its domination was staged outside the 
world of the cities, and how the population might have perceived it. The third section, "Measuring the World à la romaine", asks how Romans assessed, categorised, re-arranged, and used various landscapes, for instance regarding agricultural activities. It also deals with the political and juridical (re-)organisation of territories and the economic use and exploitation of the land. The contributions in this part highlight the development of the heterogeneous landscapes under Roman rule, which evolved into an interconnected economic, political, and cultural entity and thus created a 'Roman' world. The final fourth section, "The Semantics of Roman Landscape Representations", focuses on notions of landscape in Roman literature, in performed Roman cult, in art, as well as in the iconography of a map. It thus deals with ideal and idealised conceptions of nature and space under Rome's influence depicted in wall-paintings and described in philosophical contemplations, public speeches, and Latin poetry. Analyses of geographical depictions of the Roman world reveal similar ideas; the Tabula Peutingeriana is among the most famous examples.

The papers of the second section, "What Have the Romans Ever Done for Them?" focus on Roman infrastructure and its impact on political landscapes. Anne Kolb's "Redacta in formam provinciae: Überlegungen zu Rolle und Funktion der viae publicae" presents a synoptic overview over the Roman road network and discusses its fundamental importance for the general functioning of the Imperium Romanum as well as its impact on various Mediterranean landscapes during the imperial period. Roads connected different regions and helped to form a political, military, economic, and ideological unity. They gave the empire's inhabitants the opportunity to increase their mobility, which influenced migration. ${ }^{13}$

Filippo Carlà-Uhink's "The Impact of Roman Roads on Landscape and Space: The Case of Republican Italy" highlights the manifold interactions of Roman politics with space in the context of the construction of the Roman road system in Republican Italy. He focuses on how the enormous effort of the road construction resulted in a long-term connectivity between urban communities of the steadily growing Imperium Romanum. These new opportunities for participation in official affairs changed the public perception of the organisation of places and the distance between them. The Roman road

13 See the contributions in E. Lo Cascio and L.E. Tacoma (eds.), The Impact of Mobility and Migration in the Roman Empire [IMEM 22] (Leiden and Boston 2016). 
system was a subtle instrument of hegemonic power, which led to the crystallisation of urban hierarchies in various regions of the Italian peninsula as well as to the definition of (regional) centres and peripheries.

Sergio España-Chamorro's "Engaging Landscapes, Connecting Provinces: Milestones and the Construction of Hispania at the Beginning of the Empire" investigates the complex configuration of the administrative system in Hispania during the early Principate. He analyses the importance and functions of milestones in provincial territories within the context of landscape archaeology. The origin and rise of 'road epigraphy' on the Iberian Peninsula can be linked to a new perception of territorial space, rooted in the conception of provincial structures under Augustus. In case of the province Baetica, milestones were used specifically to promote the new administrative organisation of the territory and thus imitated the epigraphic habit already established in Italy. In Lusitania, on the other hand, no comparable signs for a comprehensive network of roads publicly represented by milestones exist, apart from rare cases under Nero. The small number of milestones on the via Augusta in Hispania Citerior probably shows that the Roman administration paid little attention to milestones as an instrument of imperial domination. España-Chamorro interprets the varied use of road epigraphy in these provinces as part of a flexible 'grand strategy' of the Roman state under the Julio-Claudian emperors, which served to assure their rule in newly conquered territories.

Camilla Campedelli's "The Impact of Roman Roads and Milestones on the Landscape of the Iberian Peninsula" examines the socio-political implications of road construction and milestones. Major parts of the via Augusta, which connected the province of Baetica with Gaul and Italy, already existed before the Roman conquest. Therefore, the beginning Roman domination had no major physical impact on this road within the landscape of Hispania. Nevertheless, a specific Roman landscape was created on the peninsula. This was achieved through the construction of solid pavements, bridges, and arches, which, in addition to the adaptation of the Roman mile system and inscribed milestones, monumentalised the Iberian road system. In the southern regions of Hispania and in the Pyrenees, however, Roman road workers transformed the physical landscape by cutting through, straightening, balancing, and levelling parts of the area to connect urban centres of the Roman provinces.

Sabine Lefebvre's "Les milliaires tardifs, une réception particulière de l'autorité impériale. Un paysage particulier le long des voies de Lusitanie" carries on with the theme of the function of milestones. She focuses on rural Lusitania's via XxIV (Via de la Plata) in the period of the political and military crises of the $3^{\text {rd }}$ and early 4 th centuries CE. Some rulers seemingly took the opportunity to present themselves to the provincial population on milestones, 
although they did not necessarily invest in constructing new or rebuilding existing roads. The increasing omission of concrete information on distances and the change from the nominative case (indicating action) to the dative case (praising the object) when the name of the emperor is given indicate that around 305 CE milestones were no longer primarily intended for the orientation of travellers on their way. Instead, they offered provincial administrators and local elites the opportunity to demonstrate their loyalty to the rulers of the later Roman empire. At least in the most western parts of the empire, the imperially dominated landscape under Roman rule had seemingly turned into a provincial landscape within the Roman empire.

Saskia Kerschbaum's "Romanization and Beyond: Aqueducts and their Multilayered Impact on Political and Urban Landscapes in Roman Asia Minor" closes this part on infrastructure with a focus on the various interactions between the cities' elites and the emperors regarding the funding, placement, and functioning of aqueducts. As Kerschbaum highlights the vital importance of water supply and its prestige in the competition between poleis in Asia minor, it becomes clear that aqueducts played a fundamental role for a specific Roman notion of urbanitas and for the every-day life in Greco-Roman cities in the east.

\section{$2 \quad$ Measuring the World}

The third section of this volume, "Measuring the World à la romaine", highlights shifting assessments, classifications, functions, and adaptations of landscape and its use for and within the Roman empire. The consequences of Rome's growing influence were not determined from the outset and did not necessarily develop straightforwardly to, for instance, more productivity or a general increase of well-being. This section starts with Günther Schörner's "Changing Landscapes under Roman Impact: Interdisciplinary Research in Northern Etruria", which analyses the transformation of the Italian landscape. Centuriation was a pervading intervention and had long-lasting effects on landscapes within the Roman empire. ${ }^{14}$ Schörner argues that the allotment

14 Since 2004, Agri Centuriati, an international, peer-reviewed journal of landscape archaeology dedicated to the phenomenon of centuriation is published annually. It includes papers on registration patterns, juridical problems, and administration, on soil quality and agrarian patterns, on the relationship of city and territory, and on dependency and territorial hierarchisation with its effects on villages in or near a Roman colony as one of the many consequences for the political, social, and economic order of a region or a specific colony, like Cremona in Italy or Corinth in Greece. 
of land to colonists and the accompanying divisions, farmsteads, and termination-stones had dramatic consequences for land ownership and the land itself and made a landscape Roman. This was, however, not the result of a 'Romanising' strategy or of specific goals for the design of Italian landscapes, which were under the control of Roman officials. The landscapes created in northern Etruria under Roman rule must rather be understood as landscapes of 'Etruscan memory'. This approach reflects how their past had been shaped and superimposed by the Roman state.

Tradition and, in this case, "Celto-Roman memory" is of major importance for the research methodology and results of Xavier Deru's and Rémi Auvertin's contribution "Des territoires celtiques aux cités romaines en Gaule septentrionale". The authors get us closer to the consequences of the transformation of Celtic territories in Gaul under Rome's political, economic, cultural, and legal influence. The division of formerly tribal territories, which had been connected primarily through family ties, language, religious practices, or trade networks, created new boundaries and borders. The Roman state established these new regions on a case-by-case basis. By negotiating, they took tradition and existing structures into consideration, favouring some local groups and families to the detriment of others. Previous identities, often reflected on numismatic remains, were redefined as people looked to the important urban centres, a process that created new socio-political and legally binding territories. These new Roman communal and social settings served as political, economic, cultural, and legal knots and orientation within the Roman provincial structure. The communities of Roman Gaul reassessed their self-image as inhabitants of the Imperium Romanum. This process resulted in the creation of long-term and stable governmental structures.

Francesco Bono's "Adluvionum ea natura est, ut semper incerta possessio sit: Picturing and Regulating Alluvial Lands in Nov. Theod. 20" examines juridical attempts to regulate the Roman landscape in late antiquity. In his analysis of Theodosius's II Novella 20, which deals with questions of ownership of alluvial land, he addresses its instability in general and the resulting consequences for jurisdiction. Theodosius II created legal security and reassured rightful ownership of these territories in order to guarantee legal and political stability in the regions affected by his decision, i.e., in this case the areas near the Egyptian Nile. His verdict reaffirmed the rights of owners of riparian land and aimed at preventing migration and rural depopulation. In response to the continuous transformation of Rome's landscape, the emperor thus re-affirmed territorial boundaries on a legal level with the intention to create stable socio-political and economic structures.

Eli Weaverdyck explores the impact of "Auxiliary Forts and Rural Economic Landscapes on the Northern Frontier" by applying targeted, quantitative 
spatial modelling. He assesses the functions of auxiliary forts as marketplaces, as well as their impact on the rural economic landscapes at the northern frontier. Case studies from the lower Danube and the lower Rhine regions serve as examples. Instances of increased sensitivity to local landscape features might suggest agricultural intensification. However, the results vary within each area of research, which indicates that Roman occupation as well as local responses to it were flexible throughout the early imperial and the late antique periods. Although many forts were centres within a landscape, it seems that the rural population did generally not perceive them as markets. The economic functions of auxiliary forts must therefore be examined on a case-by-case basis. The most obvious changes in the perception of the northern landscapes occurred around $300 \mathrm{CE}$, when at least some data indicates that inhabitants started to prefer settlement areas which allowed withdrawal, defence, and security, whereas in previous centuries the quality of agricultural land and market opportunities had been of primary importance. Even if Roman colonial foundations and permanent military installations such as colonies, analysed by Schörner, and camps, considered by Weaverdyck, had an obvious impact on the socio-political landscape by changing possibilities of property-holding and by creating hierarchies of soil, owners, and citizens, Weaverdyck also underlines the potential of sanctuaries for the local elites' self-representation. In pre-Roman communities and regions, cults and sacred places had internally supported, if not created identity. These mechanisms included manipulating and connecting existing rituals and sites according to the needs of the dominating groups. The Roman intervention in the religious sphere and on cult sites outside the Roman city models coloniae and municipiae varied in intensity and form. ${ }^{15}$ However, even where Roman impact was barely visible, like in many cults of the Near East or Egypt, the new cultic order persisted for centuries, and at least divinity-assimilations and the devotion of the emperor spread all over the empire. The resulting Romanness of a sacred landscape differed widely and it is hardly possible to cover all regions within one study.

In this volume, only one paper addresses this topic. "Imperial Cult Processions and Landscape in the Greek Cities of the Roman Empire: The

15 Most studies dealing with Roman impact on sacred landscapes have a regional focus as, e.g., the pioneering works of S. Alcock, Graecia Capta: The Landscapes of Roman Greece (Cambridge 1993), 172-214 and T. Derks, 'The transformation of landscape and religious representation in Roman Gaul', Archaeological Dialogues 4 (1997), 126-147, or the contributions in the volume of Stek and Burgers 2015, op. cit. (n. 2) challenging the modern urban-rural division of cults and the notion of a rather small impact on cult affairs during the Republican period. For the notion of "sacred landscapes" see below Marietta Horster's contribution in this volume. 
Case of the Demosthenia of Oenoanda" focuses on the socio-political context within one Greco-Roman ritual landscape in the eastern part of the empire. Elena Muñiz-Grijalvo and Fernando Lozano discuss a case of shifting notions of landscape in Asia Minor under Roman rule. The authors present a new interpretation of the epigraphic dossier on the introduction of the socalled Demosthenia, written by C. Iulius Demosthenes in Oenoanda in Lycia from $124 \mathrm{CE}$. They focus particularly on the importance of rural communities around the city during the conduct of public feasts within the framework of the imperial cult. Public worship of the emperor offered new forms of and opportunities for coexistence and cooperation between the city and the surrounding territory, leading to the active inclusion of members of Oenoanda's neighbouring villages during the festive acts. The establishment of the imperial cult ultimately led to the creation of a specific Roman landscape on a cultural, social, economic, and political level without necessarily altering the region's physical properties.

Nikolas Hächler's "Post hos nostra terra est. Mapping the Late Roman Ecumene with the Expositio totius mundi et gentium" ends the second section of the book with the portrayal of the Roman world in a late antique geographical treatise. According to the so-called Expositio totius mundi et gentium, landscape is mainly characterised by the relations between the fertile land and its adaptive inhabitants, the interconnectivity of economic and cultural hubs, and a strong mainstream culture, which includes various regions into a coherent Roman world. The geographical treatise compares the structures, organisation, and functionality of the Imperium Romanum with other communities. In contrast to the Persians and the Saraceni, for instance, the Roman empire does not wage war against its neighbours. According to the expositio-treatise, Rome's society is able to adapt to its environment, as it assesses, changes, and domesticates the landscapes of the Mediterranean world, and thereby ultimately mirrors the fortunate existence of Edenic cultures.

\section{The Semantics of Landscape Representations}

The fourth section of this volume, "The Semantics of Roman Landscape Representations", explores the appreciation and representation of landscapes in Roman literature and art, as well as their depiction on maps. It analyses the semantic meanings of these visual and literary representations within varying historical and cultural contexts. Isabel Köster's contribution "Making and Unmaking Roman Landscapes in Cicero and Caesar" examines differing accounts of Gallia in the writings of Cicero and Caesar and assesses the political and military background of the Gallic Wars. By persuasively adapting the 
notion of "anti-landscape", which was coined by the environmental historian David Nye, she presents two divergent perspectives on Gaul's landscape and its future within the Roman empire. According to Cicero, this ill-defined and uncontrollable region does not resemble a Roman landscape. Although it has been conquered by Caesar, by its 'nature' it is unsuited to become Roman. Caesar, however, presents to his readers a hostile but often orderly landscape that can potentially be controlled by Rome. From his point of view, Gaul's inhabitants counteract the land's true nature by resisting its conquest by Rome. Both authors share the notion that humans cannot change a landscape's character. A landscape either lends itself to Roman conquest or remains an "anti-landscape" and repeatedly denies the possibility of establishing Roman civilisation.

In contrast to this, Anne Gangloff demonstrates how the Roman authors Seneca and Pliny the Younger insist on the potential of human impact for creating a new landscape by changing its raison d'être. In "Paysages et otium au debut du Haut-Empire", Gangloff shows the changing functions of the Roman villae in the first century $\mathrm{CE}$ as described and perceived by the elite. With the establishment of the Principate, the villa's perception changed. In the eyes of the rich and learned senatorial elite, the villa no longer served as a political gathering point for senators far away from Rome and from the emperor, but rather as an important basis for literary production and intellectual activities in general. Quite often, its owners used it as a place of personal retreat, for instance for philosophical reflection focussing on a personal 'inner' landscape. In this individualised world of the elite members, villae and their territories became playgrounds for shaping and surpassing nature according to Roman aesthetics.

Notions of such idealised landscapes of otium were also represented in Roman art and sometimes depicted in villae and urban residences. In this context, Abigail Walker interprets "The Landscape and Nature of the Cyclops in Campanian Wall-Painting". Mythical landscapes on paintings were not simply a background for the interaction of protagonists such as Polyphemus and Galatea. These landscapes became active agents within the narratives on display. This approach allows the author to reveal the tensions between the cruel nature of the cyclops (in poetry) and the usually peaceful and idyllic groves he resides in to court his desired sea nymph (in wall-paintings). The land-sea encounter in these representations is mirrored by the meeting of the two lovers. This mythical landscape is depicted as a liminal space, which does not allow fixed and long-term relations.

These multi-layered landscape representations reflect the skilful literary adaptations appreciated by members of the Roman elite. Del Maticic explores one example. "Hercules, Cacus and the Poetics of Drains in Aeneid 8 
and Propertius" focuses on the literary representation of the battles between Hercules and the earth giant Cacus as well as on the allusions to drainage in these writings. By importing Hercules into a specifically Roman context as "Master of Waters", both poets comment upon the ethics and symbolism of Rome's water consumption. They thus associate the mythological hero's deeds with the creation of new waterways and subterranean channels. The connotations of the term barathrum, which Vergil uses for the exposed caves of Cacus, confirm this notion. On the one hand, this connects Arcadian and Roman waterworks within the landscape (re-)created by the poets and thereby successfully bridges time and two different landscapes of the Roman empire. On the other hand, Hercules's deeds are an implicit commentary on the excessive Roman water consumption and the comprehensive building activities under Augustus.

Christopher Chinn's “Empire and Italian Landscape in Statius: Silvae 4.3 and 4.5" demonstrates how imperial politics influenced the poetical landscape in Statius' oeuvre. The poet often appropriates representations of landscapes from his literary predecessors, including Vergil's pastoral Golden Age, the Aeneid's prehistoric landscapes of Italy, and Horace's rural retreats. Statius puts his depictions of landscape into the context of the political realities of his time. Additionally, his depictions at times idealise the current condition of the Roman state. Thus, the Golden Age, which is characterised in a speech of the river god Vulturnus, becomes a metaphor that praises the improvements resulting from the channelisation of the river under Domitian. The Sibyl's monologue by Statius adapts the history of the empire and particularly Aeneas's conquests. It thus allows the reader to explore the newly accessible Campanian coast while it simultaneously emphasises the emperor's control over the landscape. Finally, the so-called Severus Ode reveals the economic underpinnings of Horace's rural moralising by reconnecting the Horatian landscape to the physical world.

A different landscape representation with few words but many icons is analysed by Silke Diederich. "Empire and Landscape in the Tabula Peutingeriana" concerns the internal semantics of the Tabula Peutingeriana. Diederich interprets the document as an elaborate narrative depicting the history and organisation of Rome's imperial landscape. The map presents the known world as an all-accessible, well-structured space under the beneficial care of the Roman government and permeated by an elaborated (albeit idealised) network of roads, which connect various nodes of interest. The mapmaker arranged the known world by matching seemingly natural river-mountain-systems to the political and cultural borders of the Imperium Romanum. He thus indicates that nature itself shaped the form of the Roman empire. The Tabula Peutingeriana 
claims that the Roman state rules over the known landscape in concordance with a divine cosmic order.

\section{$4 \quad$ Impact of Empire}

Each conference of the "Impact of Empire"-series and each of its published proceedings focuses on a different angle of interactions and changes within the Roman empire. As part of this IMEM-tradition, in this book on the impact of the Roman empire on the landscape, the authors and editors were able to take up and continue some of the earlier studies, especially those on the transformation of economic life, on religion and ritual, on army and frontiers, on mobility and migration, and also the last published proceedings on the impact of justice. ${ }^{16}$ Since its foundation in Nijmegen in 1999, the international network is committed to interdisciplinarity, the promotion of young researchers and, above all, joint work on understanding the impact of the Roman empire, to which these international proceedings make a contribution. A landscape may be the result and symbol of a power relation, but they represent as well the cultural practice of all parties involved.

16 L. de Blois and J. Rich (eds.), The Transformation of Economic Life under the Roman Empire [IMEM 2] (Amsterdam 2002); L. de Blois, P. Funke and J. Hahn (eds.), The Impact of Imperial Rome on Religions, Ritual and Religious Life in the Roman Empire [IMEM 5] (Leiden and Boston 2006); L. de Blois and E. Lo Cascio (eds.), The Impact of the Roman Army (200 BC-AD 476): Economic, Social, Political, Religious and Cultural Aspects [IMEM 6] (Leiden and Boston 2007); O.J. Hekster, S. Schmidt-Hofner and C. Witschel (eds.), Ritual Dynamics and Religious Change in the Roman Empire [IMEM 9] (Leiden and Boston 2009); O.J. Hekster and T. Kaizer (eds.), Frontiers in the Roman World [IMEM 13] (Leiden and Boston 2011); D. Slootjes and M. Peachin (eds.), Rome and the World beyond its Frontiers [IMEM 21] (Leiden and Boston, 2016); Lo Cascio and Tacoma 2016, op. cit. (n. 12); O. Hekster and K. Verboven (eds.), The Impact of Justice on the Roman Empire [IMEM 34] (Leiden and Boston 2019). 